\title{
Inheriting the National Culture, Carrying Forward the National Spirit and Creating the Characteristics of Ethnic Education---The Practice of Creating Characteristic Schools in Chongqing Minority Middle School
}

\author{
Shixiong Yang, Renjun Guo
}

\begin{abstract}
Chongqing Minority Middle School (Chongqing 400082), Dadukou District, Chongqing Tuo Jia Au 39, 15600586370, China
\end{abstract}

Keywords: heritage national culture, educational characteristics.

\begin{abstract}
China is a unified multi-ethnic country created by the people of all ethnic groups. To carry out national knowledge education, national unity education, to strengthen the national spirit and spiritual education of the times, to promote the party's national theory and national policy, national laws and regulations into the classroom, into the teaching materials, into the mind, and guide teachers and students firmly establish the Marxist view of the motherland, Concept, the concept of religion, the concept of culture, shaping the national unity and national spirit of our national unity, and raising the awareness of all ethnic groups to safeguard the unity of the motherland, national unity and opposition to division, enhance the centripetal force and cohesion of all ethnic groups, Self-esteem, self-confidence and pride, and cultivate them as qualified builders and reliable successors with good ideological quality and moral accomplishment to ensure that our country is invincible in the fierce international competition and ensure the realization of a well-off society in an all- To achieve the grand goal of modernization, to ensure that the cause of socialism with Chinese characteristics flourished, followed by someone to ensure the realization of the great rejuvenation of the Chinese nation, with significant and far-reaching strategic significance.
\end{abstract}

\section{The connotation of national education}

Only by clearly defining the concept of national education and accurately grasping the connotation of national education can we clarify the main contents of national education and take effective measures to implement national education.

When it comes to ethnic education, people tend to equate national education with the education of ethnic minorities. Some of the national education is equivalent to the education of ethnic minority areas, or for the education of ethnic minorities, or minority students to receive education; some of the national education is equivalent to traditional culture and education, and some national education is equivalent to national knowledge education, these knowledge has a special and limitations.

Domestic and foreign experts and scholars on the definition of the concept of national education divergent views, but summed up there are five kinds of argument: a single national education that the national education that the minority education that the multiple meaning that cross-cultural education. In a multi-ethnic country, both the subject and the minority, have their own unique traditional culture. In the long history of human development, due to the national self-cultural transmission and the intercultural communication between the various cultures in the formation of the "you have me", "I have you" characteristics. Not only the main ethnic culture absorbed the minority culture, but also the minority culture also marked the main national culture brand, formed in a multi-ethnic country family, a variety of national culture coexist and together constitute a multi-ethnic National "common cultural groups".

\section{The main content of national education}

According to the "Outline of the Implementation of Patriotism Education", "Education Law of the People's Republic of China", "Opinions of the CPC Central Committee and State Council on Further 
Strengthening and Improving the Ideological and Moral Construction of Minors", " Unification Education Guidance Outline (Trial) ","The primary and secondary schools to carry forward and carry out the implementation of national spirit education", the party's 16th, 17th report, "national long-term education reform and development plan" and other party education policy and national policy analysis, national education should include National culture knowledge, national policy, national theory, national spirit of the four aspects of the main content.

(1) National culture knowledge education

The main contents include: the origin of the main nation (name, meaning, origin, development), national customs, customs, traditional festivals, costumes, food culture, traditional crafts, traditional sports, folk songs, folk dance, Literature and art, architectural features, science and technology, national stories, national myths and legends, religious beliefs, national cultural celebrities, heroes, national spirit, geographical distribution and so on. Correctly understand the characteristics of all ethnic groups, popularize national knowledge, let students understand the essence of the national culture of the motherland, deepen the students' love of national culture, enhance the understanding of the Chinese nation and the understanding of history and culture, and promote the mutual cultural traditions of 56 ethnic groups Exchange, inherit and carry forward; to promote the students of all ethnic groups in China to create a great history of the motherland's understanding, to stimulate students' national pride.

(2) National policy propaganda

Ethnic policies include: national equality policy, national unity policy, national regional autonomy policy, minority policy, ethnic minority and ethnic minority areas economic and social development policy, national language and text policy, national customs policy, religious freedom policy. So that the majority of teachers and students firmly establish the "three inseparable" ("Han cannot be separated from ethnic minorities, ethnic groups cannot be separated from the Han nationality, the peoples cannot be separated from each other"), "three respect" (respect and development Ethnic groups, respect for the customs and religious beliefs of ethnic minorities), oppose national division, oppose ethnic discrimination, safeguard and develop the equality, solidarity and mutual assistance of all ethnic groups, and promote the common struggle of all ethnic groups prosper".

(3) Common sense education of national theory

The main contents include: the general laws and ways of the emergence, development and demise of ethnic and ethnic issues; the content, nature and essence of ethnic issues in different social conditions; the relationship between ethnic and class issues; the relationship between national problems and social development problems; the basic principles, conditions, basic characteristics and basic contents of the formation of socialist ethnic relations; the basic principles, positions and methods of the proletariat and its political parties dealing with ethnic issues. To understand the basic characteristics of our national problems, to learn Marxism and the basic theory of the party's nationalities, to establish a Marxist view of the nation; from the historical and world perspective to analyze and explore various ethnic phenomena, to further understand the party and the national policy of the superiority ; To think in reality, to explore, in the ideological and behavioral training to implement the party and the national policy of the basic quality and ability.

(4) National spirit education

National spirit is the Chinese people in the long-term common life and common social practice in the formation and development of the majority of members of the nation recognized and accepted by the ideological character, value orientation and moral norms, the Chinese nation's language habits, psychological characteristics, Cultural traditions, thoughts and feelings of a comprehensive reflection. Primary and secondary schools to cultivate and carry forward the national spirit of education to patriotism education as the core, to the traditional Chinese virtues and revolutionary tradition of education as the focus, specific to the national consciousness, cultural identity, civic personality education. 


\section{The main way to create a national education school}

In 2008, after many demonstrations, the school decided to national education as a school characteristic. To determine the "ten one" of the transmission measures (singing a national song, jumping a national dance, painting a national painting, will be a national science and technology skills, a national class, wearing a national costume, a group National school-based teaching materials, to carry out a national festivals, to participate in a national sports activities, the construction of a national characteristics of the campus). Through the environment culture, curriculum construction, subject research, artistic characteristics, community activities, to explore the content of ethnic education, ways, cultural connotation, to build national education characteristics of school culture system, rooted in traditional culture, heritage national spirit, highlight national characteristics.

(1) Mining the concept of culture, the establishment of national education direction

Combined with the school software construction, with the cultural ideas as the carrier, lead the development of national education. We put the research of the subject research and the school philosophy culture, and put forward the concept of "national family propriety, family and all things" in the development of national education, and established the thought of "one two three four five six schools." That is, a school of philosophy: "and the United States three years, happy life"; two goals: the achievements of teachers, students only students; three standards: conducive to the healthy growth of students, is conducive to the realization of self-worth, is conducive to the rapid and rapid development of schools; Big strategy: the construction of ecological classroom, the implementation of education, nurturing national sports projects, highlighting the characteristics of national education; Five action: to build and co-management culture, to build and teachers team, development and music courses, the implementation of ecological class, the implementation of education and moral education, cultivate four grid and harmonious and happy juvenile. Six kinds of culture: cultural environment: harmonious beauty, beauty and pleasant, harmonious management culture: good beauty, beauty Master, curriculum culture: harmonious and happy beauty, to beautify the people, teachers team and culture: heart beauty, aesthetic education, student culture: warm beauty, beautiful home to adults. School network culture: harmonious beauty, beauty touching.

(2) To build a curriculum culture, enhance the national and cultural literacy of teachers and students

Classroom teaching is the main front of the construction of the characteristics of the school, the school implementation of curriculum reform: First, the subject textbooks as the carrier permeate the national culture, carry forward the national spirit. The national culture and the national spirit of the educational content of the implementation of the language, history, ideological and moral, geography, music, sports, art and other disciplines, so that students feel the national culture, enhance national pride. Second is the development of school-based curriculum, school-based materials as a carrier, and heritage of national culture, to stimulate national feelings. Organized teachers to prepare the "national education simple reading", "national song concise tutorial", "national sports concise tutorial", "folk art" and other ethnic education school-based materials, and into the school curriculum system, arrange full-time teachers to teach. So that students understand the national minorities folk customs, national festivals, national eating habits, national instrumental music, national songs, national costumes, national art and other national culture, improve the national and cultural literacy of teachers and students to enhance national pride. The third is to carry out the research of ethnic education, tap the cultural connotation of ethnic education, explore the way of national education and carrier, build our school national education characteristic system, and cultivate students' national unity quality and patriotism emotion. Our school-based subject "National School of Education characteristics of the school-based strategy research" research results by participating in the end of the City Board of Education related to the leadership of a high degree of recognition, smooth results and municipal scientific research third prize.

(3) Enrich the activities of culture, highlighting the highlights of national education

One is the big class exercises. By the Tujia waved dancing waved hand have become a school class intercourse, and the city campus television program second prize. 
Second is the theme of education activities as the carrier, to promote the growth of all teachers and students.

In order to gather national feelings, show students talent, the development of student personality, we use spare time to theme education activities as the carrier, moral education and the Communist Youth League to carry out different forms of national education activities to promote the growth of all teachers and students. Mainly in the class, ceremonies, traditional festivals, spare time; folk songs and dances, folk art, folk sports, traditional virtues, model deeds, heroes, historical stories and other content; performances, lectures, lectures, essays, sports, Watch and other forms of educational activities; gather national unity and strength to promote the comprehensive development of students.

Three is held every year, "five", display features. "New Year's Day" national folk song and dance, March National Folk Fun Sports Festival, "Red May" national folk song, September national unity and progress publicity week activities, November reading festival, cultivate students mind, improve student literacy. 5 wrestling judo players to participate in the third session of the Games in Chongqing, made three first, two second good results; class gymnastics - waved the city to run the Municipal Excellence Award ; National television program won the third prize; every year in September, our school organized by the national unity and progress education and publicity activities are subject to the city, district and other leaders spoke highly of.

(4) Love to help national students, boost national unity and progress

The school organized a small group of students to the Chongqing auditorium, zoo, martyrs tombs to visit the traditional festivals such as the Mid-Autumn Festival, Dragon Boat Festival, New Year's Day, May 1, the organization of national dinner activities ; To carry out minority students and party members and teachers, minority students and Han students to help activities; the implementation of the policy of subsidizing minority students, the full reduction of minority junior high school students all the costs to ensure that minority students in school safe learning, Creating a "national family pro, home and everything" cultural atmosphere. Each class to carry out a national unity as the theme of the theme of the class, the school every year in recognition of national unity and progress model class collective and individual, cultivate the typical, set an example, to create a national unity and friendship atmosphere. Implement teachers to visit student system. Monthly class teacher at least once in-depth students, concerned about the national students of learning, living conditions, to keep abreast of their needs, to resolve contradictions, to protect their interests, with the truth care of its healthy growth.

Our school is the "Chongqing National Unity and Progress Promotion Association" units, the State Ethnic Affairs Commission, the National People's Congress, the CPPCC, the government, the public and other leaders at all levels to visit our school to guide the national education work, Of the national education work has been praised; has won the "Chongqing national education advanced collective", "Chongqing City, the socialist civilization etiquette demonstration school", "Chongqing garden-style units", "Chongqing security and civilized campus", " "Chongqing City, according to the law school demonstration school", "Chongqing national unity and progress demonstration unit", "Chongqing national unity and progress model unit" honorary title, the school has been recommended by the public to participate in the "national unity and progress Create activities demonstration unit "declaration (the city recommended a total of four units).

Characteristic school is the development of teachers, students grow the paradise. Ethnic education is not only to create a national cultural atmosphere of the campus, but also give full play to the role of the main channel of classroom education and the theme of educational activities, extracurricular activities, but also to promote the development of national education, Expand the educational space. Therefore, to carry out national education, to deepen the curriculum reform, improve moral education work, enrich the extracurricular activities, the construction of campus culture, promote school management, enrich the connotation of running a school, comprehensively promote quality education, is the source of birth. Polish national characteristics of business cards, write a happy growth chapter, will be our eternal pursuit. National spirit education 


\section{Conclusion}

It is necessary to create national education characteristics and national spirit education to inherit the culture of national culture, to establish the direction of running the national education, to improve the moral education work, to enrich the extracurricular activities, to build the campus culture, to promote the school management, to enrich the connotation of running schools and promote the comprehensive development of students.

\section{Acknowledgements}

Author brief introduction: Yang Shixiong (1971.8- ), male, undergraduate, Bachelor of science, senior teachers Research direction: management and curriculum reform.

\section{References}

[1] School education Inheritance of national traditional culture problems and the way out [J]. Jing Dongge, Sun Zhendong. Journal of South-Central University for Nationalities (Humanities and Social Sciences). 2014 (06)

[2] Moral education should focus on promoting individuality in accordance with individualized teaching [A]. Zhang Xiuying .2013 Hebei Province class teacher forum Proceedings [C]. 